Vol. 1 No. 2, September 2020

P-ISSN: 2746-0967, E-ISSN: 2721-656X

\title{
Kedudukan State Auxiliary Organ dalam Sistem Ketatanegaraan di Indonesia
}

Kelik Iswandi ${ }^{1}$, Nanik Prasetyoningsih ${ }^{2}$

Fakultas Hukum Universitas Muhammadiyah Yogyakarta, E-mail: kelik.iswandi.2016@law.umy.ac.id, ${ }^{1}$ nanikprasetyoningsih@umy.ac.id ${ }^{2}$

INFO ARTIKEL

\author{
Perjalanan Artikel: \\ Artikel Dikirimkan oleh \\ penulis: $14-05-20$ \\ Artikel Direview: 15-05-20 \\ Artikel Direvisi: 24-08-20 \\ Artikel Diterima atau \\ Dipublikasikan: 24-08-20
}

DOI: $10.18196 / j p h k .1208$

\section{Pendahuluan}

\section{ABSTRAK}

Penelitian ini dilakukan untuk mengkaji kedudukan state auxiliary organ yang merupakan Lembaga negara resmi negara tetapi tidak dijelaskan dengan rinci kedudukan state auxiliary organ dalam konstitusi. Pembagian kekuasaan pada cabang-cabang khusus kekuasaan dalam negara hukum bertujuan untuk menghindari terpusatnya kekuasaan pada satu titik yang berakibat kesewenangwenangan. Indonesia tidak menerapkan pembagian kekuasaan trias politica secara murni. Di Indonesia lembaga negara terbagi menjadiconstitutional state organdan state auxiliary organ. Constitutional state organ memiliki kedudukan yang sangat jelas dalam ketatanegaraan, tetapi state auxiliary organ tidak memiliki kedudukan yang jelas. State auxiliary organ sendiri terbentuk dengan berbagai macam variasi bentuk yang berdampak terhadap ketidakjelasan kedudukannya. Metode analisis deskriptif dipergunakan dalam penelitian hukum normatif untuk menganalisis data sekunder yang diperoleh melalui kajian kepustakaan. Penelitian ini menunjukkan bahwa state auxiliary organ di Indonesia memiliki berbagai kedudukan. Kedudukan state auxiliary organ dapat ditentukan melalui kedudukan berdasarkan aturan pembentuknya, kedudukan berdasarkan independensi kelembagaannya, dan kedudukan berdasarkan tugas dan fungsinya.

Kata Kunci: Constitutional State Organ, State Auxiliary Organ, Trias Politica

Indonesia merupakan negara hukum. Pembagian kekuasaan dalam penyelenggaraan negara dijalankan dalam konsepsi negara hukum. Tujuan dari adanya pembagian kekuasaan agar tidak terpusatnya kekuasaan pada satu tangan untuk menghindari timbulnya penyalahgunaan kekuasaan atau power tends to corrupt, absolut power corrupt absolutely. Dalam penyelenggaraan kekuasaan di Indonesia dilakukan oleh lembaga negara.

Lembaga negara di Indonesia dibagi menjadi dua macam yakni constitutional state organ dan state auxiliary organ. Constitutional state organ ialah lembaga negara yang kewenangannya diberikan oleh Undang-Undang Dasar 1945. Sedangkan, state auxiliary 
organ ialah lembaga negara yang kewenangannya diberikan bukan oleh UndangUndang Dasar 1945 tetapi oleh peraturan perundang-undangan lainnya. ${ }^{1}$ Beberapa state auxiliary organ walaupun kewenangannya dibentuk oleh peraturan perundangundangan lainnya tetapi terdapat pula kewenangan konstitusionalnya.

Di Indonesia, state auxiliary organ berkembang pesat setelah adanya reformasi. Lembaga ini dibentuk baik oleh Presiden ataupun Dewan Perwakilan Rakyat. ${ }^{2}$ Terbentuknya state auxiliary organ ialah dikarenakan kondisi birokrasi yang terdapat pada lingkungan pemerintah dinilai tidak mampu lagi memenuhi kebutuhan masyarakat akan pelayanan umum dengan pedoman kualitas mutu yang senantiasa meningkat. ${ }^{3}$ Perkembangan state auxiliary organ yang semakin pesat berdampak pada kedudukan state auxiliary organ itu sendiri. Hal ini dikarenakan tidak ada satupun dasar hukum yang mengatur terkait dengan kedudukan state auxiliary organ di Indonesia. Lantas bagaimana idealnya kedudukan state auxiliary organ dalam system ketatanegaraan di Indonesia.

\section{Metodologi}

Metode yang digunakan dalam penelitian ini ialah metode penelitian yuridis normatif dengan menggunakan data sekunder yang diperoleh dari hasil studi kepustakaan. Bahan penelitian ini menggunakan bahan hukum primer, sekunder, dan tersier. Metode analisis yang digunakan dalam penelitian ini ialah analisis deskriptif dengan metode pendekatan peraturan perundang-undangan dan pendekatan konsep.

\section{Analisis dan Hasil}

\subsection{Impelementasi Pembagian Kekuasaan di Indonesia}

Pasal 1 ayat (3) Undang-Undang Dasar 1945 menyebutkan bahwa Indonesia ialah negara hukum. Acuan pokok penyelenggaraan kekuasaan negara dalam konsepsi negara hukum ialah hukum itu sendiri. ${ }^{4}$ Konsepsi negara hukum memiliki sejarah panjang dalam perumusannya. ${ }^{5}$ Konsepsi negara hukum secara tidak tegas dikemukakan oleh Plato dengan konsep nomoi yang kemudian diperkuat oleh Aristoteles dalam bukunya yang berjudul politica. ${ }^{6}$

Terdapat dua istilah dalam menyebutkan konsepsi negara hukum yakni konsep rechtsstaat yang digunakan pada sistem hukum eropa continental dan konsep

\footnotetext{
1 Tim Pengkajian Hukum Tentang Hubungan Antar Lembaga Negara. (2005). Laporan Akhir Pengkajian Hukum Tentang Hubungan Lembaga Negara Pasca Amandemen UUD 1945. Jakarta: Badan Pembinaan Hukum Nasional. hlm. 19.

2 Zainal Arifin Mochtar dan Iwan Satriawan. (2009). “Efektivitas Sistem Penyeleksian Pejabat Komisi Negara di Indonesia". Jurnal Konstitusi 6 (3). hlm. 146.

${ }^{3}$ Jimly Asshiddiqie. (2016). Perkembangan \& Konsolidasi Lembaga Negara Pasca Reformasi. Cet. III. Jakarta: Sinar Grafika. hlm. 25.

${ }^{4}$ CST Kansil. (2002). Pengantar Ilmu Hukum dan Tata Hukum Indonesia. Jakarta: Balai Pustaka. hlm. 3.

${ }^{5}$ Ni'matul Huda. (2005). Negara Hukum, Demokrasi, dan Judicial Review. Yogyakarta: UII Press. hlm. 1.

${ }^{6}$ Ridwan HR. (2006). Hukum Administrasi Negara. Jakarta: PT. Raja Grafindo Persada. hlm. 2.
} 
rule of law yang digunakan pada sistem hukum anglo-saxon. Utrecht membedakan negara hukum menjadi dua golongan yakni negara hukum formil dan negara hukum materiil. ${ }^{7}$ Negara hukum formil (negara hukum klasik) ialah pengertian dari negara hukum dalam arti sempit atau hanya terbatas pada peraturan perundang-undangan. Sedangkan, negara hukum materiil ialah pengertian dari negara hukum dalam arti luas yang mencakup konsep keadilan yang harus ditegakkan pada hukum tersebut. Dalam perkembangan negara hukum modern, terdapat perbedaan dalam merumuskan negara hukum. ${ }^{8}$ Hal ini bergantung pada rumusan masing-masing negara yang menerapkan prinsip negara hukum.

Di Indonesia sendiri terdapat salah satu unsur negara hukum dalam UndangUndang Dasar 1945 yakni adanya sistem konstitusi. ${ }^{9}$ Konsep penting dari negara hukum yang menjadi prinsip utama dalam menjalankan pemerintahan ialah adanya pemisahan kekuasaan. ${ }^{10}$ Kekuasaan negara terbagi kedalam cabang-cabang khusus berdasarkan pada jenis-jenis kekuasaan dengan ketentuan masing-masing kekuasaan dijalankan oleh lembaga negara tersendiri. ${ }^{11}$

John Locke menjadi pelopor konsepsi pembagian kekuasaan dan membagi kekuasaan kedalam tiga cabang kekuasaan yakni, kekuasaan eksekutif, kekuasaan legislatif, dan kekuasaaan federatif. ${ }^{12}$ Konsep tersebut dikembangkan oleh Montesquie dengan konsep pemisahan kekuasaan (trias politica). ${ }^{13}$ Konsep pemisahan kekuasaan menghendaki kekuasaan dipisahkan kedalam kekuasaan legislatif, kekuasaan eksekutif, dan kekuasaan yudikatif. ${ }^{14}$ Adapun dasar pemisahaan kekuasaan tersebut ialah pada fungsi-fungsi pemerintahan. ${ }^{15}$

Terdapat perbedaan dari kedua pendapat tersebut. Perbedaan ditunjukkan pada kategorisasi cabang kekuasaan. John Locke mengklasifikasikan kekuasaan yudikatif kedalam kekuasaan eksekutif. ${ }^{16}$ Sedangkan, Montesquie mengklasifikasikan kekuasaan federatif kedalam kekuasaan eksekutif dan memandang kekuasaan yudikatif harus berdiri sendiri terpisah dengan kekuasaan lain. ${ }^{17}$

Prinsip checks and balances menjadi suatu pedoman penerapan pemisahan kekuasaan dengan tujuan adanya control dari satu lembaga negara ke lembaga negara

\footnotetext{
7 Utrecht. (1962). Pengantar Hukum Administrasi Negara Indonesia. Jakarta: Ichtiar. hlm. 9.

8 Rozikin Daman. (1993). Hukum Tata Negara. Jakarta: PT. Raja Grafindo Persada. hlm. 167.

9 Sayuti. (2011). "Konsep Rechtsstaat Dalam Negara Hukum Indonesia (Kajian Terhadap Pendapat Azhari". Nalar Fiqh Jurnal Kajian Ekonomi dan Kemasyarakatan 4 (2). hlm. 97.

10 Janpatar Simamora. (2014). “Tafsir Negara Hukum Dalam Prespektif Undang-Undang Dasar Negara Republik Indonesia Tahun 1945". Jurnal Dinamika Hukum 14 (3). hlm. 553.

11 Tim Penyusun Hukum Acara Mahkamah Konstitusi. (2010). Hukum Acara Mahkamah Konstitusi. Jakarta: Sekretariat Jenderal dan Kepaniteraan Mahkamah Konstitusi Republik Indonesia. hlm. 4.

${ }^{12}$ Hamdan Zoelva. (2001). Pemakzulan Presiden di Indonesia. Jakarta: Sinar Grafika. hlm. 61.

${ }^{13}$ Ismail Suny. (1982). Pembagian Kekuasaan Negara. Jakarta: Aksara Baru. hlm. 1-2.

${ }^{14}$ CST Kansil. (2004). Ilmu Negara Umum dan Indonesia. Jakarta: Pradnya Paramita. hlm. 70.

15 Suparto. (2016). "Pemisahan Kekuasaan, Konstitusi dan Kekuasaan Kehakiman yang Independen Menurut Islam". Jurnal Selat 4 (1). hlm. 116.

${ }^{16}$ Gunawan A Tauda. (2012). Komisi Negara Independen. Yogyakarta: Genta Press. hlm. 52.

17 Miriam Budiardjo. (2002). Dasar-Dasar Ilmu Politik. Jakarta: Gramedia. hlm. 150.
} 
lain. ${ }^{18}$ Sehingga dapat ditafsirkan bahwa prinsip checks and balances ialah prinsip saling mengimbangi antar cabang kekuasaan negara. ${ }^{19}$ Dalam perkembangan sistem pemerintahan modern, teori pemisahaan kekuasaan tidak dapat dijalankan secara murni dan memunculkan lembaga negara baru. ${ }^{20}$ Selain itu, lembaga negara juga diberikan lebih dari satu fungsi. ${ }^{21}$ Beberapa negara juga melaksanakan teori pemisahan kekuasaan dengan berbagai model. ${ }^{22}$ Beberapa contoh negara yang menerapkan prinsip pemisahan kekuasaan (separation of powers) ialah Inggris, Amerika Serikat, dan Indonesia. Inggris dalam menerapkan prinsip (separation of powers) tidak menerapkannya secara mutlak melainkan menggabungkan cabang kekuasaan eksekutif dan legislatif dalam artian perdana menteri harus merangkap sebagai anggota parlemen. Amerika Serikat menyempurnakan ajaran Montesquie dengan dengan ajaran checks and balances agar tidak menimbulkan masalah gridlock dengan tujuan agar pemerintahan dapat berjalan efektif. Sedangkan di Indonesia, implementasi separation of power dilakukan dengan adanya kewenangan eksekutif dalam membentuk undang-undang. ${ }^{23}$

Adanya persoalan yang kompleks yang dihadapi negara-negara di dunia menjadi dasar negara-negara di dunia menyatakan diri sebagai negara kesejahteraan (welfare state). Dasar dari konsep kesejahteraan ialah adanya pengawasan terhadap penyelenggaraan negara. ${ }^{24}$ Konsep tersebut tidak dapat dilaksanakan oleh suatu cabang kekuasaan dan mengharuskan adanya kerja sama antar cabang kekuasaan yang ada. ${ }^{25}$

Implementasi di Indonesia berdasarkan Undang-Undang Dasar 1945 menggunakan paham kekuasaan secara vertikal bukan pemisahan kekuasaan secara horizontal. Pendapat tersebut dilatarbelakangi dengan adanya supremasi MPR sebelum amandemen Undang-Undang Dasar 1945. Setelah amandemen UndangUndang Dasar 1945 yang menempatkan kedudukan lembaga tinggi negara berada dalam satu garis. Hal ini merupakan amanah dari Pasal 1 ayat (2) Undang-Undang Dasar 1945 setelah amandemen yang menyatakan bahwa kedaulatan berada ditangan rakyat dan dilaksanakan berdasarkan Undang-Undang Dasar 1945.

Kekuasaan di Indonesia dibagi berdasarkan bidang khusus, suatu bidang ditangani oleh satu lembaga atau satu kekuasaan khusus di bidang tersebut. Akan

\footnotetext{
18 Sunarto. (2016). "Prinsip Checks and Balances dalam Sistem Ketatanegaraan Indonesia". Jurnal Masalah-Masalah Hukum 45 (2). hlm. 158.

${ }^{19}$ Zulkarnain Ridlwan. (2015). “Cita Demokrasi Indonesia Dalam Politik Hukum Pengawasan DPR Terhadap Pemerintah". Jurnal Konstitusi 12 (2). hlm. 312.

${ }^{20}$ Gunawan A Tauda. Op. Cit. hlm. 52.

${ }^{21}$ Utrecht. Op.Cit. hlm. 17-24.

${ }^{22}$ Haposan Siallagan. (2015). "Problematics on Separation of Power Theory Implementation". Jurnal Dinamika Hukum 15 (3). hlm. 325.

${ }^{23}$ Zulfan. (2018). “Analisis Pengaturan dan Praktik Pemisahan Kekuasaan Sistem Pemerintahan Presidensial Berdasarkan Konstitusi". Jurnal Media Hukum 25 (1). hlm. 65

${ }^{24}$ W. Riawan Tjandra (2014). Hukum Sarana Pemerintahan. Jakarta: Cahaya Atma Pustaka. hlm. 1.

25 Juanda. (2006). Hukum Pemerintahan Daerah Pasang Surut Hubungan Kewenangan DPRD dan Kepala Daerah. Bandung: Alumni. hlm. 74.
} 
tetapi, dalam perkembangannya terdapat bidang khusus yang ditangani oleh beberapa lembaga negara.

Di Indonesia kekuasaan dibagi menjadi lima cabang kekuasaan sebelum amandemen Undang-Undang Dasar 1945 dan empat cabang kekuasaan setelah amandemen Undang-Undang Dasar 1945, yakni: ${ }^{26}$

\section{a. Kekuasaan legislatif}

Kekuasaan legislatif merupakan kekuasaan pembuatan undangundang. Kekuasaan ini harus diserahkan kepada suatu lembaga khusus. Lembaga ini sangat berperan penting dalam pembentukan peraturan perundang-undangan dan sebagai penopang tiang demokrasi. Lembaga ini terlahir dari pilihan rakyat melalui pemilu yang merupakan bentuk nyata dari demokrasi prosedural. ${ }^{27} \mathrm{Hal}$ ini dikarenakan pemilu merupakan hal yang tidak dapat dipisahkan dari implementasi demokrasi di suatu negara. ${ }^{28}$ Selain itu, kekuasaan legislatif juga memiliki fungsi sebagai penyerap aspirasi masyarakat dan mempertimbangkan aspirasi rakyat dalam proses pembentukan undangundang guna memberikan koridor dalam penyelenggaraan negara. ${ }^{29}$ Proses pembentukan undang-undang dilakukan dengan adanya Rancangan UndangUndang yang berasal dari Dewan Perwakilan Rakyat, Dewan Perwakilan Daerah, dan Presiden. Setiap RUU harus dilengkapi dengan naskah akademik kecuali untuk RUU Anggaran dan Pendapatan Belanja Negara, RUU Penetapan Perpu Menjadi UU, dan RUU Pencabutan Perpu atau Pencabutan UU. Selanjutnya RUU ditindaklanjuti dengan dua tingkat pembicaraan yakni pembicaraan I ditingkat rapat ditingkat komisi dan pembicaraan II ditingkat rapat paripurna. RUU yang telah mendapat persetujuan bersama antara Presiden dan DPR kemudian disahkan oleh DPR. ${ }^{30}$ Di Indonesia, sebelum

\footnotetext{
${ }^{26}$ Efi Yulistyowati, Endah Pujiastuti, dan Tri Mulyani. (2016). "Penerapan Konsep Trias Politica Dalam Sistem Pemerintahan Republik Indonesia: Studi Komparatif atas Undang-Undang Dasar Tahun 1945 Sebelum dan Sesudah Amandemen". Jurnal Dinamika Budaya 18 (2). hlm. 335-337. 27 Nanik Prasetyoningsih. (2014). "Dampak Pemilihan Umum Serentak bagi Pembangunan Demokrasi Indonesia". Jurnal Media Hukum 21 (2). hlm. 242.

${ }^{28}$ Kelik Iswandi. (2019). "Media Sosial dan Partai Politik Baru" dalam Ni'matul Huda, dkk. (2019). Mewujudukan Daulat Rakyat Melalui Pemilu yang Berkualitas. Yogyakarta: Pustaka Pelajar bekerja sama dengan LP3M UMY dan PK2P UMY. hlm. 196.

${ }^{29}$ Septi Nur Wijayanti dan Kelik Iswandi. (2018). "Pengaruh Parliamentary Threshold terhadap Partisipasi Publik" dalam Nanik Prasetyoningsih, Tanto Lailam, dan Putri Anggia (Editor). (2018). "Menagih Komitmen Pemerintah Mewujudkan Keadilan Sosial". Proceedings Seminar Nasional dan Call for Papers. Yogyakarta: LP3M UMY. hlm. 107.

${ }^{30}$ Lihat Pasal 16 sd Pasal 23, Pasal 43 sd Pasal 51, dan Pasal 65 sd Pasal 74 Undang-Undang Nomor 12 Tahun 2011 tentang Pembentukan Peraturan Perundang-Undangan dan
} 
adanya amandemen Undang-Undang Dasar 1945 dijalankan oleh dua lembaga yakni Majelis Permusyawaratan Rakyat dan Dewan Perwakilan Rakyat. Kemudian, setelah amandemen Undang-Undang Dasar 1945, kekuasaan legislatif dijalankan oleh Majelis Permusyawaratan Rakyat, Dewan Perwakilan Rakyat, dan Dewan Perwakilan Daerah.

b. Kekuasaan eksekutif

Kekuasaan eksekutif merupakan kekuasaan pelaksana undang-undang. Kekuasan ini dijalankan oleh Presiden dan Wakil Presiden yang dibantu oleh para Menteri. Baik setelah amandemen maupun sesudah amandemen UndangUndang Dasar 1945, kekuasaan eksekutif dijalankan oleh Presiden. Meskipun Presiden sebagai pemegang kekuasaan eksekutif yang berarti pelaksana undang-undang. Tetapi di Indonesia, Presiden juga memiliki fungsi sebagai pembentuk undang-undang meskipun bukan pemegang utama. Hal ini tertuang dalam Pasal 20 ayat (1) Undang-Undang Dasar 1945 dimana dalam pasal tersebut, Presiden diberikan kewenangan untuk ikut membahas rancangan undang-undang tersebut. Tidak hanya itu, dalam Pasal 5 ayat (1) Undang-Undang Dasar 1945 menyatakan bahwa Presiden berhak mengajukan rancangan undang-undang ke Dewan Perwakilan Rakyat. Selain itu, dalam Pasal 5 ayat (2) Undang-Undang Dasar 1945, Presiden memiliki kewenangan untuk menetapkan peraturan pemerintah dan dalam Pasal 22 Undang-Undang Dasar 1945, Presiden memiliki kewenangan untuk membuat peraturan pemerintah pengganti undang-undang dalam keadaan ikhwal memaksa.

\section{c. Kekuasaan yudikatif}

Kekuasaan yudikatif merupakan kekuasaan untuk mempertahankan undang-undang dan sebagai pengawas pelaksanaan undang-undang. Kekuasaan yudikatif atau kekuasaan kehakiman memiliki kewenangan menyelenggarakan proses peradilan. Proses peradilan yang dijalankan oleh yudikatif ialah proses peradilan yang mandiri bebas campur tangan kekuasaan manapun. Kekuasaan kehakiman sebelum amandemen Undang-Undang Dasar 1945 dijalankan oleh Mahkamah Agung. Seiring dengan adanya tuntutan reformasi yang dilanjutkan oleh amandemen Undang-Undang Dasar 1945, kekuasaan kehakiman dijalankan oleh Mahkamah Agung dan Mahkamah Konstitusi. Mahkamah Agung memiliki kewenangan dalam mengadili perkara

perubahannya. Lihat juga Pasal 162 sd Pasal 173 Undang-Undang Nomor 17 Tahun 2014 tentang MD3 dan perubahannya. 
ditingkat akhir, kewenangan menguji peraturan perundang-undangan dibawah undang-undang terhadap undang-undang, serta kewenangan lain yang ditentukan dalam undang-undang. Sedangkan Mahkamah Konstitusi memiliki kewenangan dalam menguji undang-undang terhadap UndangUndang Dasar, memutus sengketa kewenangan konstitusional lembaga negara, memutus pembubaran partai politik, dan memutus sengketa hasil pemilihan umum. ${ }^{31}$

\section{d. Kekuasaan konsultatif}

Kekuasaan konsultatif merupakan kekuasaan yang memberikan nasehat kepada kekuasaan eksekutif. Kekuasaan ini terdapat dalam UndangUndang Dasar 1945 sebelum amandemen. Kekuasaan konsultatif dipegang oleh Dewan Pertimbangan Agung. Kemudian setelah amandemen UndangUndang Dasar 1945, kekuasaan ini dihapuskan dan diganti dengan Dewan Pertimbangan Presiden (Watimpres) yang masuk ke dalam ranah kekuasaan eksekutif.

\section{e. Kekuasaan eksaminatif}

Kekuasaan eksaminatif merupakan salah satu cabang kekuasaan yang memiliki kewenangan untuk memeriksa keuangan negara. Baik sebelum maupun sesudah amandemen Undang-Undang Dasar 1945, kekuasaan eksaminatif dipegang oleh Badan Pemeriksa Keuangan.

Di Indonesia pasca amandemen Undang-Undang Dasar 1945, terdapat beberapa prinsip dasar dalam pendistribusian kekuasaan negara, yakni: ${ }^{32}$

1) Meninggalkan prinsip supremasi parlemen menuju ke negara hukum dengan supremasi konstitusi, dibuktikan dengan adanya Mahkamah Konstitusi sebagai penjaga dan penegak konstitusi.

2) Menerapkan prinsip pemisahan kekuasaan dan melaksanakan sistem redistribusi kekuasaan serta membentuk lembaga-lembaga negara baru yang dirancang untuk memberikan penguatan sistem presidensialisme.

\footnotetext{
${ }^{31}$ Ketentuan lebih lanjut terkait dengan kekuasaan kehakiman dapat dilihat pada UndangUndang Nomor 48 Tahun 2009 tentang Kekuasaan Kehakiman.

32 Moh. Fajrul Falaakh. (2009). "Redistribusi Kekuasaan Negara dan Model Hubungan Antarlembaga Negara dalam UUD 1945 Pasca Amandemen". Laporan Penelitian. Yogyakarta: WCRU-HTN Fakultas Hukum UGM. hlm. 91. Lihat juga dalam Gunawan A Tauda. (2012). Op. Cit. hlm. 74-76.
} 
3) Terdapat penegasan independesi kekuasaan yudikatif dan dibentuknya Mahkamah Konstitusi yang menyebabkan adanya kekuasaan yang memiliki struktur ganda.

4) Lembaga-lembaga negara memiliki kedudukan yang sejajar dengan adanya prinsip checks and balances, dan tidak lagi menerapkan hierarki pyramidal.

\subsection{Lembaga Negara di Indonesia}

Lembaga negara merupakan wujud dari kelengkapan negara yang memiliki fungsi untuk menjalankan kekuasaan dan mewujudkan cita-cita negara. ${ }^{33}$ Berbagai ragam dan bentuk organisasi negara berkembang dalam beragam variasi struktur dan fungsi organisasi negara. Perkembangan organisasi negara dikarenakan tuntutan kebutuhan dalam proses bernegara. ${ }^{34}$ Perubahan signifikan terjadi terhadap organisasi negara disemua negara. Terjadi perubahan bentuk organiasi negara yang awalnya berbentuk departemen pemerintahan kemudian dewasa ini berubah menjadi dewan dan komisi-komisi. Bentuk-bentuk organisasi berupa departemen pemerintahan ada pada masa pemerintahan awal kemerdekaan (Orde Lama). Kemudian sejak permulaan Orde Baru hingga saat ini muncul lembaga-lembaga baru berupa lembaga, komisi, badan yang berfungsi sebagai pelaksana pemerintahan yang merupakan bentuk tindak lanjut dari konstitusi. ${ }^{35}$ Serta penggunaan istilahistilah departemen mulai ditinggalkan. Bahkan terdapat pula komisi yang bersifat ad hoc. ${ }^{36}$ Dewasa ini, terdapat perbedaan penyebutan lembaga negara di Indonesia. Lembaga negara yang terbentuk memiliki nomenklatur yang berbeda-beda diantaranya lembaga, badan, atau komisi. ${ }^{37}$ Terjadi perdebatan dikalangan ahli terkait dengan penyebutan nomenklatur lembaga negara.

Lembaga negara diartikan sebagai organisasi atau badan kenegaraan. ${ }^{38}$ Lembaga negara atau civilated organization memiliki makna bahwa lembaga negara tersebut dibentuk oleh negara, dari negara, untuk negara dengan tujuan untuk

\footnotetext{
33 A. Fickar Hadjar, dkk. (2003). Pokok-Pokok Pikiran dan Rancangan Undang-Undang Mahkamah Konstitusi. Jakarta: KRHN dan Kemitraan. hlm. 4.

34 Jimly Asshiddiqie. (2016). Perkembangan \& Konsolidasi Lembaga Negara Pasca Reformasi. Op. Cit. hlm. 1.

35 Hendra Nurtjahjo. (2005). “Lembaga, Badan, dan Komisi Negara Independen (State Auxiliary Agencies) di Indonesia: Tinjauan Hukum Tata Negara”. Jurnal Hukum dan Pembangunan 35 (3). hlm. 275.

36 Ibid. hlm. 25.

37 Refly Harun, et. al. (2004). Menjaga Denyut Nadi Konstitusi: Refleksi Satu Tahun Mahkamah Konstitusi. Jakarta: Konstitusi Press. hlm. 60-65.

38 Andi Hamzah. (1986). Kamus Hukum. Jakarta: Ghalia Indonesia. hlm. 349.
} 
membangun negara tersebut. 39 Istilah "lembaga-lembaga negara" dikukuhkan penggunaannya dalam Ketetapan MPRS No. XX/MPRS/1996.40 Jimly Asshiddiqie berpandangan bahwa pengertian dari lembaga negara tidak hanya dibatasi dengan pengertian lembaga negara secara umum. ${ }^{41}$ Akan tetapi juga perlu diartikan secara luas. 42

Dalam konsep organisasi negara terdapat dua unsur pokok yang saling terkait yaitu organ dan functie. Organ merupakan tempatnya sedangkan functie merupakan isi dari organ tersebut sesuai dengan tujuan dari pembentuknya. ${ }^{43}$ Dari sudut pandang hukum tata negara positif (positieve staatsrecht), lembaga negara diartikan sebagai organ negara yang secara umum menjadi materi muatan dalam konstitusi suatu negara. ${ }^{44}$

Kurang luwesnya amandemen konstitusi membuat lembaga negara yang dibentuk hanya terbatas sehingga berdampak pada pembentukan lembaga negara berdasarkan peraturan perundang-undangan lainnnya. ${ }^{45}$ Pembentukan lembaga negara berdasarkan peraturan perundang-undangan lainnya menjadi solusi aplikatif demi menciptakan pembagian kekuasaan yang baik.

Lembaga negara yang dibentuk dan memiliki kewenangan berdasarkan konstitusi disebut sebagai constitutional state organ. Sedangkan, lembaga negara yang dibentuk dan memiliki kewenangan berdasarkan peraturan perundang-undangan lainnya disebut sebagai state auxiliary organ. Dalam mengklasifikasikan lembaga negara, Sri Soemantri mengklasifikasikan dua sistem ketatanegaraan yakni sistem ketatanegaraan dalam arti sempit dan arti luas. Sistem ketatanegaraan dalam arti sempit meliputi lembaga-lembaga negara yang terdapat dalam Undang-Undang Dasar 1945. Sedangkan, yang dimaksud dari sistem ketatanegaraan dalam arti luas meliputi seluruh lembaga negara baik lembaga negara yang terdapat didalam maupun diluar Undang-Undang Dasar 1945.46

\footnotetext{
${ }^{39}$ Mustafa Luthfi dan M. Iwan Satriawan. (2014). Meneropong Komisi Informasi Publik". Malang: UB Press. hlm. 13.

${ }^{40}$ Asri Agustiwi. (2014). “Keberadaan Lembaga Negara Pasca Amandemen Undang-Undang Dasar 1945 di Indonesia". Jurnal Rechstaat Ilmu Hukum Fakultas Hukum UNSA 8 (1). hlm. 5.

41 Jimly Asshiddiqie. (2005). Sengketa Kewenangan Antar Lembaga Negara. Cet. 1. Jakarta: Konstitusi Press. hlm. 31.

42 Ibid. hlm. vii.

43 Jimly Asshiddiqie. (2006). Perkembangan dan Konsolidasi Lembaga Negara Pasca Reformasi. Jakarta: Sekretariat Jenderal dan Kepaniteraan Mahkamah Konstitusi RI. hlm. 99.

${ }^{44}$ Widodo Ekatjahjana dan Totok Sudaryanto. (2001). Sumber Hukum Tata Negara Formal di Indonesia. Bandung: PT. Citra Aditya Bhakti. hlm. 19-20.

${ }^{45}$ Tim Penyusun Hukum Acara Mahkamah Konstitusi. Op. Cit. hlm. 4.

${ }^{46}$ Ahmad Basarah. (2014). "Kajian Teoritis Terhadap Auxiliary State's Organ Dalam Struktur Ketatanegaraan Indonesia". Jurnal MMH 43 (1). hlm. 3
} 
Klasifikasi lembaga negara juga disampaikan oleh G. Jellinek, berdasarkan pandangannya lembaga negara diklasifikasikan kedalam lembaga negara langsung (unmitterbar) dan lembaga negara tidak langsung (mitterbar). Unmitterbar ialah lembaga negara yang dibentuk langsung dan keberadaannya ditentukan oleh konstitusi, sedangkan mitterbar ialah lembaga negara yang keberadaannya bergantung pada lembaga negara langsung. ${ }^{47}$

Bagir Manan membedakan lembaga negara ke dalam tiga jenis, yakni: 48

a. Alat kelengkapan negara, yaitu lembaga negara yang menjalankan fungsi negara secara langsung yang bertindak untuk dan atas nama negara, seperti Presiden dan Wakil Presiden, Dewan Perwakilan Rakyat, Kekuasaan kehakiman.

b. Lembaga administratif, yaitu lembaga negara yang memiliki fungsi administratif yang tidak bersifat ketatanegaraan. Atau dapat diartikan tidak bertindak untuk dan atas nama negara melainkan hanya menjalankan fungsi administratif.

c. State auxiliary organ/agency/bodies, yaitu lembaga negara yang memiliki fungsi sebagai penunjang dari fungsi lembaga negara yang termasuk dalam alat kelengkapan negara.

Jimly Asshiddiqie ${ }^{49}$ memberikan klasifikasi lembaga negara ke dalam tiga lapis, diantaranya lembaga lapis pertama yaitu lembaga tinggi negara, lapis kedua yaitu lembaga negara, dan lapis ketiga ialah lembaga daerah. Klasifikasi lembaga negara pada lapis pertama terdiri oleh lembaga tinggi negara. Lembaga tinggi negara merupakan lembaga negara yang kewenangannya disebutkan langsung dalam Undang-Undang Dasar 1945. Lembaga tinggi negara diantaranya:

a. Majelis Permusyawaratan Rakyat,

b. Presiden dan Wakil Presiden,

c. Dewan Perwakilan Rakyat,

d. Dewan Perwakilan Daerah,

47 Padmo Wahyono. (2003). Ilmu Negara. Jakarta: Indo Hill. Co. hlm. 222.

48 Novianto M. Hantoro. (2016). “Klasifikasi Jabatan dalam Kelembagaan Negara: Permasalahan Kategori Pejabat Negara". Jurnal Negara Hukum 7 (2). hlm. 148.

${ }^{49}$ Jimly Asshiddiqie. (2006). Perkembangan dan Konsolidasi Lembaga Negara Pasca Reformasi. Op. Cit. hlm. 106-113. 
e. Mahkamah Agung,

f. Mahkamah Konstitusi,

g. Badan Pemeriksa Keuangan.

Kemudian lembaga negara pada lapis kedua ialah lembaga negara. Pada lapis ini terdapat lembaga negara yang memperoleh kewenangan dari Undang-Undang Dasar 1945 dan terdapat pula yang memiliki kewenangan berdasarkan undangundang. Jimly Asshiddiqie berpandangan bahwa walaupun kewenangan lembaga negara diberikan oleh Undang-Undang Dasar 1945 atau dapat dikatakan memiliki constitutional importance tetapi lembaga negara tersebut belum tentu lembaga negara utama. Hal ini dikarenakan:50

a. Fungsinya hanya sebagai supporting/auxiliary terhadap fungsi lembaga negara utama,

b. Kewenangan yang disebutkan secara eksplisit dalam Undang-Undang Dasar 1945 bertujuan untuk memberikan ketegasan independensi konstitusional,

c. Kewenangan yang diberikan dalam Undang-Undang Dasar 1945 hanya berupa kewenangan pokok yang bersifat by implication, tidak dirumuskan secara tegas. Lembaga-lembaga negara yang termasuk dalam klasifikasi lapis kedua ialah:

a. Menteri Negara,

b. Tentara Nasional Indonesia,

c. Kepolisian Negara,

d. Komisi Yudisial,

e. Komisi Pemilihan Umum,

f. Bank Sentral.

Klasifikasi berikutnya adalah lembaga negara lapis ketiga. Pada klaster ini, termuat lembaga-lembaga daerah, diantaranya:

a. Pemerintahan Daerah Provinsi,

b. Gubernur,

c. DPRD Provinsi,

d. Pemerintahan Daerah Kabupaten,

e. Bupati,

f. DPRD Kabupaten,

g. Pemerintahan Daerah Kota,

h. Walikota,

50 Ibid. 
i. DPRD Kota.

Kemudian, Murtir Jeddawi memberikan kategori organ-organ negara menjadi dua kategori, yakni lembaga negara dan lembaga negara independen. ${ }^{51}$ Dalam kategori lembaga negara beranggotakan Majelis Permusyawaratan Rakyat, Dewan Perwakilan Rakyat, Dewan Perwakilan Daerah, Presiden dan Wakil Presiden, Mahkamah Agung, Mahkamah Konstitusi, Komisi Yudisial, dan Badan Pemeriksa Keuangan. Sedangkan yang termasuk dalam kategori lembaga negara independen ialah Komisi Pemilihan Umum, Komisi Nasional Hak Asasi Manusia, Tentara Nasional Indonesia, Kepolisian Republik Indonesia, Bank Indonesia, dan Ombudsman.

\section{a. Constitutional State Organ}

Constitutional state organ merupakan lembaga negara yang kewenangannya diamanatkan langsung oleh Undang-Undang Dasar 1945. Terdapat 34 lembaga negara yang disebut keberadaannya dalam UndangUndang Dasar 1945 yaitu:

1. Majelis Permusyawaratan Rakyat yang diatur dalam Bab II Undang-Undang Dasar 1945.

2. Presiden yang diatur dalam Bab III Undang-Undang Dasar 1945.

3. Wakil Presiden yang diatur dalam Pasal 4 ayat (2) Undang-Undang Dasar 1945.

4. Menteri dan Kementrian Negara yang diatur dalam Bab V Undang-Undang Dasar 1945.

5. Menteri Luar Negeri yang diatur dalam Pasal 8 ayat (3) Undang-Undang Dasar 1945.

6. Menteri Dalam Negeri yang diatur dalam Pasal 8 ayat (3) Undang-Undang Dasar 1945.

7. Menteri Pertahanan yang diatur dalam Pasal 8 ayat (3) Undang-Undang Dasar 1945.

8. Dewan Pertimbangan Presiden yang diatur dalam Pasal 16 Undang-Undang Dasar 1945.

9. Duta yang diatur dalam Pasal 13 ayat (1) dan (2) Undang-Undang Dasar 1945.

10. Konsul yang diatur dalam Pasal 13 ayat (1) Undang-Undang Dasar 1945.

\footnotetext{
${ }^{51}$ Murtir Jeddawi. (2012). Hukum Administrasi Negara. Yogyakarta: Total Media. hlm. 155-182.
} 
11. Pemerintahan Daerah Provinsi yang diatur dalam Pasal 18 ayat (2), (3), (5), (6), dan ayat (7) Undang-Undang Dasar 1945.

12. Gubernur yang diatur dalam Pasal 18 ayat (4) Undang-Undang Dasar 1945.

13. Dewan Perwakilan Rakyat Daerah Provinsi yang diatur dalam Pasal 18 ayat (3) Undang-Undang Dasar 1945.

14. Pemerintahan Daerah Kabupaten yang diatur dalam Pasal 18 ayat (2), (3), (5), (6), dan ayat (7) Undang-Undang Dasar 1945.

15. Bupati yang diatur dalam Pasal 18 ayat (4) Undang-Undang Dasar 1945.

16. Dewan Perwakilan Rakyat Daerah Kabupaten yang diatur dalam Pasal 18 ayat (3) Undang-Undang Dasar 1945.

17. Pemerintahan Daerah Kabupaten yang diatur dalam Pasal 18 ayat (2), (3), (5), (6), dan ayat (7) Undang-Undang Dasar 1945.

18. Walikota yang diatur dalam Pasal 18 ayat (4) Undang-Undang Dasar 1945.

19. Dewan Perwakilan Rakyat Daerah Kota yang diatur dalam Pasal 18 ayat (3) Undang-Undang Dasar 1945.

20. Satuan Pemerintahan Daerah yang bersifat khusus yang diatur dalam Pasal 18B ayat (1) Undang-Undang Dasar 1945.

21. Dewan Perwakilan Rakyat yang diatur dalam Bab VII Undang-Undang Dasar 1945.

22. Dewan Perwakilan Daerah yang diatur dalam Bab VIIA Undang-Undang Dasar 1945.

23. Komisi Penyelenggaraan Pemilu yang diatur dalam Pasal 22E ayat (5) Undang-Undang Dasar 1945.

24. Bank Sentral yang diatur dalam Pasal 23D Undang-Undang Dasar 1945.

25. Badan Pemeriksa Keuangan yang diatur dalam Bab VIIIA Undang-Undang Dasar 1945.

26. Mahkamah Agung yang diatur dalam Pasal 24 dan Pasal 24A UndangUndang Dasar 1945.

27. Mahkamah Konstitusi yang diatur dalam Pasal 24 dan Pasal 24C UndangUndang Dasar 1945.

28. Komisi Yudisial yang diatur dalam 24B Undang-Undang Dasar 1945.

29. Tentara Nasional Indonesia yang diatur dalam Pasal 30 Undang-Undang Dasar 1945.

30. Angkatan Darat diatur dalam Pasal 10 Undang-Undang Dasar 1945.

31. Angkatan Laut diatur dalam Pasal 10 Undang-Undang Dasar 1945.

32. Angkatan Udara diatur dalam Pasal 10 Undang-Undang Dasar 1945. 
33. Kepolisian Negara Republik Indonesia yang diatur dalam Pasal 30 UndangUndang Dasar 1945.

34. Badan-badan lain yang fungsinya terkait dengan kekuasaan kehakiman seperti kejaksaan yang diatur dalam Pasal 24 ayat (3) Undang-Undang Dasar 1945.

\section{b. State Auxiliary Organ}

State auxiliary organ merupakan lembaga negara yang dibentuk berdasarkan peraturan perundang-undangan lain atau dikatakan bukan lembaga negara yang memiliki kewenangan yang diamanatkan oleh UndangUndang Dasar 1945. Jumlah state auxiliary organ ini sangat banyak, diantaranya:

1. Komisi Pemberantasan Korupsi yang dibentuk berdasarkan UndangUndang Nomor 30 Tahun 2002 tentang Komisi Pemberantasan Korupsi.

2. Komisi Nasional Hak Asasi Manusia yang dibentuk berdasarkan Keputusan Presiden Nomor 50 Tahun 1993 tentang Komisi Nasional Hak Asasi Manusia yang diperkuat dalam Undang-Undang Nomor 39 Tahun 1999 tentang Hak Asasi Manusia.

3. Lembaga Perlindungan Saksi dan Korban yang dibentuk berdasarkan Undang-Undang Nomor 13 Tahun 2006 yang diubah dalam UndangUndang Nomor 31 Tahun 2014 tentang Lembaga Perlindungan Saksi dan Korban.

4. Pusat Pelaporan dan Analisis Transaksi Keuangan yang dibentuk berdasarkan Undang-Undang Nomor 8 Tahun 2010 tentang Pencegahan dan Pemberantasan Tindak Pidana Pencucian Uang.

5. Komisi Pengawas Persaingan Usaha yang dibentuk berdasarkan UndangUndang Nomor 5 Tahun 1999 tentang Larangan Praktik Monopoli dan Persaingan Usaha Tidak Sehat.

6. Ombusdman Republik Indonesia yang dibentuk berdasarkan UndangUndang Nomor 37 Tahun 2008 tentang Ombusdman Republik Indonesia.

7. Komisi Penyiaran Indonesia yang dibentuk berdasarkan Undang-Undang Nomor 32 Tahun 2002 tentang Penyiaran.

8. Badan Keamanan Laut Republik Indonesia yang dibentuk berdasarkan Undang-Undang Nomor 32 Tahun 2014 tentang Kelautan yang secara teknis diatur dalam Peraturan Presiden Nomor 178 Tahun 2014 tentang Badan Keamanan Laut. 
Serta state auxiliary organ lain yang ada di Indonesia seperti Komisi Hukum Nasional, Kamar Dagang dan Industri, Komite Olahraga Nasional Indonesia, dan lain sebagainya.

\subsection{Kedudukan State Auxiliary Organ dalam Sistem Ketatanegaraan di Indonesia}

\section{a. Kedudukan State Auxiliary Organ Berdasarkan Aturan Pembentuk}

1. State Auxiliary Organ Dibentuk Berdasarkan Undang-undang

Berikut merupakan lembaga negara yang terbentuk berdasarkan undang-undang, diantaranya:

Tabel 1. State Auxiliary Organ Dibentuk Berdasarkan Undang-undang

\begin{tabular}{|c|c|}
\hline Nama State auxiliary organ & Aturan Pembentuk \\
\hline $\begin{array}{l}\text { Lembaga Perlindungan Saksi dan } \\
\text { Korban (LPSK) }\end{array}$ & $\begin{array}{l}\text { Undang-Undang Nomor } 13 \text { Tahun } 2006 \\
\text { tentang Perlindungan Saksi dan Korban }\end{array}$ \\
\hline Komisi Informasi & $\begin{array}{l}\text { Undang-Undang Nomor } 14 \text { Tahun } 2008 \\
\text { tentang Keterbukaan Informasi Publik }\end{array}$ \\
\hline Dewan Pers & $\begin{array}{l}\text { Undang-Undang Nomor } 11 \text { Tahun } 1996 \\
\text { tentang Ketentuan-Ketentuan Pokok Pers }\end{array}$ \\
\hline Komisi Pemberantasan Korupsi & $\begin{array}{l}\text { Pasal } 43 \text { Undang-Undang Nomor } 31 \text { Tahun } \\
1999 \text { tentang Pemberantasan Tindak Pidana } \\
\text { Korupsi yang kemudian ditegaskan kembali } \\
\text { dalam Undang-Undang Nomor } 30 \text { Tahun } \\
2002 \text { tentang Komisi Pemberantasan Tindak } \\
\text { Pidana Korupsi }\end{array}$ \\
\hline $\begin{array}{l}\text { Pusat pelaporan dan Analisis } \\
\text { Transaksi Keuangan (PPATK) }\end{array}$ & $\begin{array}{l}\text { Undang-Undang Nomor } 8 \text { Tahun } 2010 \\
\text { tentang Pencegahan dan Pemberantasan } \\
\text { Tindak Pidana Pencucian Uang }\end{array}$ \\
\hline Komisi Penyiaran Indonesia (KPI) & $\begin{array}{l}\text { Undang-Undang Nomor } 32 \text { Tahun } 2002 \\
\text { tentang Penyiaran }\end{array}$ \\
\hline $\begin{array}{l}\text { Komisi Pengawas Persaingan Usaha } \\
\text { (KPPU) }\end{array}$ & $\begin{array}{l}\text { Undang-Undang Nomor } 5 \text { Tahun } 1999 \\
\text { tentang Larangan Praktek Monopoli dan }\end{array}$ \\
\hline
\end{tabular}




\begin{tabular}{|c|c|}
\hline & Persaingan Usaha Tidak Sehat \\
\hline Badan Pengawas Pemilu (Bawaslu) & $\begin{array}{l}\text { Undang-Undang Nomor } 22 \text { Tahun } 2007 \\
\text { tentang Penyelenggara Pemilu }\end{array}$ \\
\hline Komisi Pemilihan Umum (KPU) & $\begin{array}{l}\text { Undang-Undang Nomor } 15 \text { Tahun } 2011 \\
\text { tentang Penyelenggara Pemilihan Umum }\end{array}$ \\
\hline Konsil Kedokteran Indonesia & $\begin{array}{l}\text { Undang-Undang Nomor } 29 \text { Tahun } 2004 \\
\text { tentang Praktik Kedokteran }\end{array}$ \\
\hline $\begin{array}{l}\text { Badan Akuntabilitas } \quad \text { Keuangan } \\
\text { Negara }\end{array}$ & $\begin{array}{l}\text { Pasal 112A sampai Pasal 112G Undang- } \\
\text { Undang Nomor } 2 \text { Tahun } 2018 \text { tentang } \\
\text { Perubahan Kedua Atas Undang-Undang } \\
\text { Nomor } 17 \text { Tahun } 2014 \text { tentang Majelis } \\
\text { Permusyawaratan Rakyat, Dewan } \\
\begin{array}{l}\text { Perwakilan Rakyat, Dewan Perwakilan } \\
\text { Daerah, dan Dewan Perwakilan Rakyat } \\
\text { Daerah (MD3) }\end{array}\end{array}$ \\
\hline Badan Keahlian & $\begin{array}{l}\text { Pasal } 413 \text { Undang-Undang Nomor } 17 \text { Tahun } \\
2014 \text { tentang Majelis Permusyawaratan } \\
\text { Rakyat, Dewan Perwakilan Rakyat, Dewan } \\
\text { Perwakilan Daerah, dan Dewan Perwakilan } \\
\text { Rakyat Daerah (MD3) dan Peraturan } \\
\text { Presiden Nomor } 27 \text { Tahun } 2015 \text { tentang } \\
\text { Sekretariat Jenderal dan Badan Keahlian } \\
\text { Dewan Perwakilan Rakyat Republik } \\
\text { Indonesia }\end{array}$ \\
\hline Badan Musyawarah & 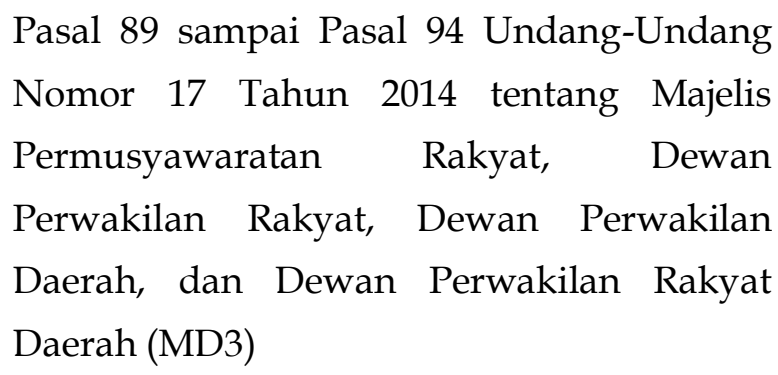 \\
\hline Badan Legislasi & $\begin{array}{lcccc}\text { Pasal } 102 & \text { sampai } & 106 & \text { Undang-Undang } \\
\text { Nomor } 17 & \text { Tahun } & 2014 & \text { tentang Majelis }\end{array}$ \\
\hline
\end{tabular}




\begin{tabular}{|c|c|}
\hline & $\begin{array}{l}\text { Permusyawaratan } \\
\text { Perwakilan Rakyat, }\end{array}$ \\
\hline Badan Anggaran & $\begin{array}{l}\text { Pasal } 107 \text { sampai Pasal } 112 \text { Undang-Undang } \\
\text { Nomor } 17 \text { Tahun } 2014 \text { tentang } \\
\text { Permusyawaratan } \\
\begin{array}{l}\text { Perwakilan Rakyat, Dewan Perwakilan } \\
\text { Daerah, dan Dewan Perwakilan Rakyat } \\
\text { Daerah (MD3) }\end{array}\end{array}$ \\
\hline Badan Kerja Sama Antar-Parlemen & 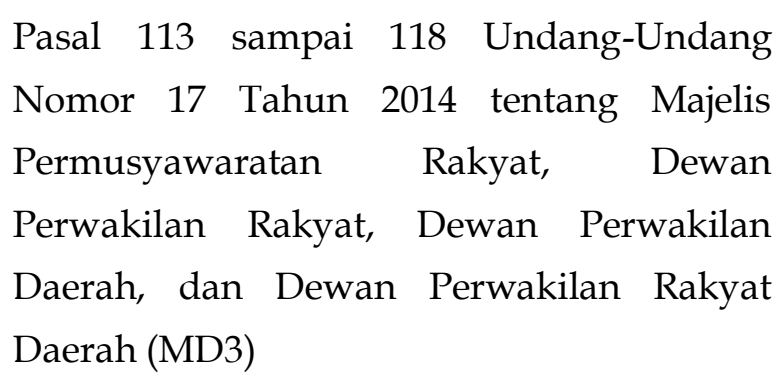 \\
\hline Mahkamah Kehormatan Dewan & 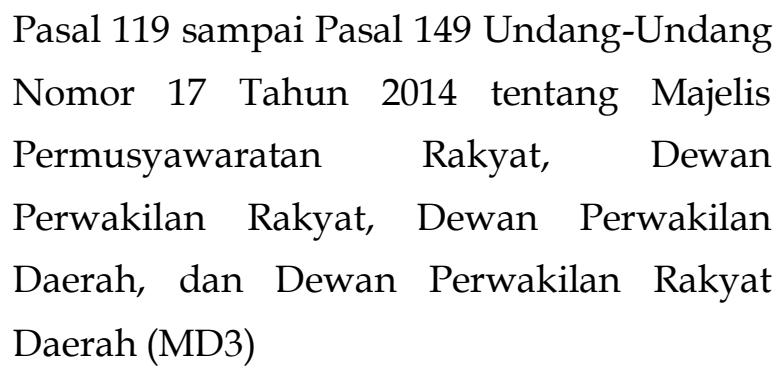 \\
\hline Badan Urusan Rumah Tangga & 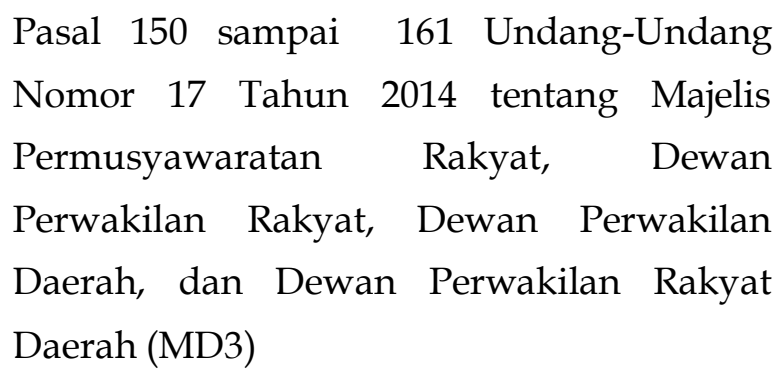 \\
\hline Dewan Pertimbangan Presiden & $\begin{array}{l}\text { Undang-Undang Nomor } 19 \text { Tahun } 2006 \\
\text { tentang Dewan Pertimbangan Presiden }\end{array}$ \\
\hline Otoritas Jasa Keuangan & $\begin{array}{l}\text { Undang-Undang Nomor } 21 \text { Tahun } 2011 \\
\text { tentang Otoritas Jasa Keuangan }\end{array}$ \\
\hline
\end{tabular}


Badan Keamanan Laut

Undang-Undang Nomor 32 Tahun 2014 tentang Kelautan yang secara teknis diatur dalam Peraturan Presiden Nomor 178 Tahun 2014 tentang Badan Keamanan Laut

Sumber: diolah dari berbagai sumber.

2. State Auxiliary Organ Dibentuk Berdasarkan Peraturan Perundang-undangan Dibawah Undang-undang

Tabel 2. State Auxiliary Organ Dibentuk Berdasarkan Peraturan Perundang-undangan Dibawah Undang-Undang

\begin{tabular}{|c|c|}
\hline Nama State Auxiliary Organ & Aturan Pembentuk \\
\hline Dewan Pendidikan & $\begin{array}{l}\text { Peraturan Pemerintah Nomor } 17 \text { Tahun } 2010 \\
\text { tentang Pengelolaan dan Penyelenggaraan } \\
\text { Pendidikan }\end{array}$ \\
\hline Komisi Perlindungan Anak & $\begin{array}{l}\text { Keputusan Presiden Republik Indonesia } \\
\text { Nomor } 77 \text { Tahun } 2003 \text { dan ditegaskan Pasal } \\
74 \text { ayat (1) Undang-Undang Nomor } 35 \\
\text { Tahun } 2014 \text { tentang Perubahan Atas } \\
\text { Undang-Undang Nomor } 23 \text { Tahun } 2002 \\
\text { tentang Perlindungan Anak }\end{array}$ \\
\hline $\begin{array}{l}\text { Komisi Nasional Anti Kekerasan } \\
\text { Terhadap Perempuan } \\
\text { Perempuan) }\end{array}$ & $\begin{array}{l}\text { Keppres Nomor } 181 \text { Tahun } 1998 \text { tentang } \\
\text { Komisi Nasional Anti Kekerasaan Terhadap } \\
\text { Perempuan yang kemudian diperbarui } \\
\text { melalui Perpres No. } 65 \text { Tahun } 2005\end{array}$ \\
\hline $\begin{array}{l}\text { Komisi Nasional Hak Asasi Manusia } \\
\text { (Komnas HAM) }\end{array}$ & $\begin{array}{l}\text { Keputusan Presiden Nomor } 50 \text { Tahun } 1993 \\
\text { tentang Komisi Nasional Hak Asasi } \\
\text { Manusia }\end{array}$ \\
\hline Ombudsman & Keputusan Presiden Nomor 44 Tahun 2000 \\
\hline
\end{tabular}


(ORI)

tentang Komisi Ombudsman kemudian diperkuat dengan adanya Undang-Undang Nomor 37 Tahun 2008 tentang Ombudsman Republik Indonesia

Dewan Ketahanan Nasional Keputusan Presiden Nomor 101 Tahun 1999 tentang Dewan Ketahanan Nasional dan Sekretariat Jenderal Dewan Ketahanan Nasional.

\begin{tabular}{ll}
\hline Lembaga Ketahanan Nasional & Peraturan Presiden Nomor 67 Tahun 2006 \\
(Lemhannas) & tentang Lembaga Ketahanan Nasional yang \\
& kemudian dilakukan perubahan dengan \\
& Keputusan Presiden Nomor 103 Tahun 2001 \\
& tentang Kedudukan, Tugas, Fungsi, \\
& Kewenangan, Susunan Organisasi, dan Tata \\
& Kerja Lembaga Pemerintah Non \\
& Departemen.
\end{tabular}

Lembaga Ilmu Pengetahuan Keputusan Presiden Nomor 1 Tahun 1986 Indonesia (LIPI) tentang Lembaga Ilmu Pengetahuan Indonesia yang kemudian dilakukan perubahan dengan Keputusan Presiden Nomor 103 Tahun 2001 tentang Kedudukan, Tugas, Fungsi, Kewenangan, Susunan Organisasi, dan Tata Kerja Lembaga Pemerintah Non Departemen.

Badan Pengkajian dan Penerapan Keputusan Presiden Nomor 25 Tahun 1978 Teknologi (BPPT) tentang Badan Pengkajian dan Penerapan Teknologi yang telah diubah Keputusan Presiden Nomor 47 Tahun 1991 tentang Badan Pengkajian dan Penerapan Teknologi.

Badan Kepegawaian Negara (BKN) Peraturan Pemerintah Nomor 32 Tahun 1972 tentang Badan Administrasi Kepegawaian Negara. 
Lembaga Administrasi Negara (LAN) Peraturan Presiden Nomor 57 Tahun 2013 tentang Lembaga Administrasi Negara.

\begin{tabular}{llll}
\hline $\begin{array}{l}\text { Badan Pariwisata dan Ekonomi } \\
\text { Kreatif }\end{array}$ & $\begin{array}{l}\text { Peraturan Presiden Nomor } 6 \text { Tahun } 2015 \\
\text { tentang Badan Ekonomi Kreatif. }\end{array}$ \\
\hline $\begin{array}{l}\text { Badan Pengawas } \\
\text { Pembangunan }\end{array}$ & Keuangan dan $\begin{array}{l}\text { Peraturan Presiden Nomor } 192 \text { Tahun } 2014 \\
\text { tentang Badan Pengawas Keuangan dan } \\
\text { Pembangunan. }\end{array}$ \\
\hline
\end{tabular}

Sumber: diolah dari berbagai sumber.

Dari tabel-tabel tersebut menunjukkan pembentukan state auxiliary organ di Indonesia dilakukan dengan berdasarkan peraturan perundang-undangan dibawah UUD 1945 seperti undang-undang, peraturan pemerintah, atau keputusan Presiden. Pembentukan state auxiliary organ melalui peraturan perundang-undangan dibawah UUD 1945 menunjukkan bahwa kurang luwesnya amandemen UUD 1945. Sedangkan kebutuhan negara akan lembagalembaga negara khusus untuk menjalankan kekuasaan negara yang semakin kompleks dan kebutuhan masyarakat akan pelayanan umum tidak dapat dihindari lagi.

\section{b. Kedudukan State Auxiliary Organ Berdasarkan Independensi Kelembagaan}

1. Lembaga Negara Independen

Kedudukan dari state auxiliary organ pun beragam, terdapat dibawah kekuasaan legislatif, eksekutif, yudikatif, atau bahkan diranah independen. Akan tetapi, lembaga negara independen masih selalu diperdebatkan oleh para ahli tata negara. Sebab tidak ada suatu patokan khusus yang diberikan oleh pembentuk lembaga mengenai kedudukannya di cabang kekuasaan mana.

Karakteristik yang dimiliki lembaga negara independen ialah:52

a) Independensi dalam menjalankan tugas dan fungsinya telah ditegaskan dalam peraturan pembentuknya (syarat normatif).

b) Makna independen ialah terbebas dari pengaruh, kontrol, ataupun kehendak dari cabang kekuasaan eksekutif.

c) Mekanisme pengangkatan dan pemberhentian anggota lembaga negara independen diatur secara khusus, tidak langsung berdasarkan kehendak Presiden (political appointee).

52 Gunawan A. Tauda. (2011). "Kedudukan Komisi Negara Independen dalam Struktur Ketatanegaraan Republik Indonesia". Jurnal Pranata Hukum 6 (2). hlm. 174. 
d) Kepemimpinan dalam lembaga negara independen memiliki sifat kolektif kolegial, besaran jumlah anggota bersifat ganjil dan pengambilan keputusan melalui mekanisme suara mayoritas.

e) Penguasaan kepemimpinan lembaga negara independen tidak berasal dari partai politik tertentu.

f) Periode jabatan kepemimpinan lembaga negara independen bersifat definitif, selesai masa jabatan secara bersamaan, dan untuk periode berikutnya dapat diangkat kembali maksimal 1 periode.

g) Lazimnya tujuan keanggotaan lembaga negara independen ialah sebagai bandul penyeimbang perwakilan dengan sifat non partisan.

Gunawan A. Tauda juga berpendapat, dalam menentukan suatu lembaga negara dapat dikatakan sebagai lembaga negara independen jika dapat memenuhi tiga unsur yakni unsur a, b, dan c. ${ }^{53}$ Gunawan A. Tauda menyebutkan lembaga negara yang termasuk kedalam lembaga negara independen, yakni: ${ }^{4}$

a) Komisi Pemilihan Umum.

b) Badan Pengawas Pemilu (Bawaslu).

c) Komisi Pengawas Persaingan Usaha (KPPU).

d) Komisi Penyiaran Indonesia (KPI).

e) Ombudsman Republik Indonesia (ORI).

f) Pusat Pelaporan dan Analisis Transaksi Keuangan (PPATK).

g) Komisi Yudisial.

h) Komisi Nasional Hak Asasi Manusia (Komnas HAM).

i) Komisi Nasional Anti Kekeraan terhadap Perempuan (Komnas Perempuan).

j) Komisi Pemberantasan Korupsi (KPK).

k) Komisi Perlindungan Anak (KPA).

1) Dewan Pers.

m) Dewan Pendidikan.

n) Komisi Informasi.

o) Lembaga Perlindungan Saksi dan Korban (LPSK).

2. State Auxiliary Organ yang Bergantung pada Constitutional State Organ

${ }^{53}$ Ibid. hlm. 175.

${ }^{54}$ Ibid. 
State auxiliary organ yang bergantung pada constitutional state organ ialah state auxiliary organ yang kedudukannya bergantung pada dan tidak dapat dipisahkan dari constitutional state organ. .55

a) Bergantung pada Dewan Perwakilan Rakyat ${ }^{56}$

1) Badan Akuntabilitas Keuangan Negara.

2) Badan Keahlian.

3) Badan Musyawarah.

4) Badan Legislasi.

5) Badan Anggaran.

6) Badan Kerja Sama Antar-Parlemen.

7) Mahkamah Kehormatan Dewan.

8) Badan Urusan Rumah Tangga.

b) Bergantung pada Presiden ${ }^{57}$

1) Konsil Kedokteran Indonesia.

2) Dewan Ketahanan Nasional.

3) Lembaga Ketahanan Nasional (Lemhannas).

4) Lembaga Ilmu Pengetahuan Indonesia (LIPI).

5) Badan Pengkajian dan Penerapan Teknologi (BPPT).

6) Badan Kepegawaian Negara (BKN).

7) Lembaga Administrasi Negara (LAN).

8) Dewan Pertimbangan Presiden.

9) Badan Pariwisata dan Ekonomi Kreatif.

10) Badan Pengawas Keuangan dan Pembangunan.

11) Badan Keamanan Laut.

\section{c. Kedudukan State Auxiliary Organ Berdasarkan Tugas dan Fungsinya}

1. Lembaga Negara Quasi

\footnotetext{
55 Badan-badan tersebut merupakan state auxiliary organ yang bergantung pada constitutional state organ. Hal ini ditunjukkan dari pembentukan lembaga negara tersebut merupakan lembaga negara yang memiliki kewenangan khusus perpanjangan tangan dari constitutional state organ.

${ }^{56}$ Lihat Undang-Undang Nomor Nomor 17 Tahun 2014 tentang MD3 dan perubahannya.

57 Umumnya lembaga-lembaga negara yang diklasifikasikan pada jenis ini dalam aturan pembentuknya disebutkan bahwa lembaga negara tersebut dikoordinasikan melalui menteri terkait dengan bidang dari lembaga negara tersebut dan lembaga negara tersebut bertanggung jawab terhadap Presiden melalui kementerian terkait.
} 
Pada umumnya state auxiliary organ memiliki sifat semi pemerintahan atau quasi, yang diberikan fungsi tunggal, atau fungsi campuran yang salah satunya disatu pihak sebagai pengatur, administratif, dan dilain sisi juga menghukum. ${ }^{58}$ Kemudian, terdapat kriteria khusus kepada lembaga negara untuk dikategorikan sebagai lembaga quasi atau bukan. Berikut merupakan keenam kriteria tersebut, yakni: 59

a) Lembaga negara memiliki kekuasaan untuk melakukan penilaian dan pertimbangan (the power to exercise judgement and discreation),

b) Lembaga negara memiliki kekuasaan untuk mendengar, menentukan, dan membuat putusan (the power to hear and determine or to ascertain facts and judgements),

c) Lembaga negara memiliki kekuasaan untuk membuat amar putusan dan membuat dasar pertimbangan yang mengikat subyek hukum dalam putusannya (the power to make binding orders and judgements),

d) Lembaga negara memiliki kekuasaan untuk mempengarungi hak orang per orang (the power to affect the personal or property right of private persons),

e) Lembaga negara memiliki kekuasaan untuk memeriksa saksi-saksi, memaksa saksi untuk hadir, dan mendengar keterangan para pihak dalam persidangan (the power to examine witnesses, to compel the attendance of witnesses, and to hear the litigation of issues on a hearing),

f) Lembaga negara memiliki kekuasaan untuk menjatuhkan sanksi hukuman (the power to enforce dicisions or impose penalties).

Berikut merupakan lembaga-lembaga negara yang berdasarkan pandangan penulis merupakan lembaga negara quasi, yakni:

a) Pusat Pelaporan dan Analisis Transaksi Keuangan (PPATK).

b) Ombudsman Republik Indonesia.

c) Badan Pengawas Pemilihan Umum.

d) Komisi Pemilihan Umum.

e) Komisi Informasi.

f) Komisi Penyiaran Indonesia.

g) Komisi Pengawas Persaingan Usaha.

h) Komisi Pemberantasan Korupsi.

58 Ibid. hlm. 341.

${ }^{59}$ Jimly Asshiddiqie. (2013). Pengadilan Khusus dalam Tim Penyusun Komisi Yudisial. (2013). Putih Hitam Pengadilan Khusus. Jakarta: Pusat Analisis dan Layanan Informasi Sekretariat Jenderal Komisi Yudisial. hlm. 17-18. 
i) Otoritas Jasa Keuangan.

2. State Auxiliary Organ Bukan Quasi

State auxiliary organ bukan quasi ialah lembaga negara yang memiliki tugas dan fungsi yang tergolong kedalam salah satu cabang kekuasaan (tidak memiliki tugas dan fungsi quasi). Lembaga negara jenis ini umumnya bersifat menunjang tugas dan fungsi dari constitutional state organ. Berikut merupakan lembaga-lembaga negara yang merupakan penunjang dari constitutional state organ, yaitu: 60

a) Kekuasaan Legislatif

1) Badan Akuntabilitas Keuangan Negara.

2) Badan Keahlian.

3) Badan Musyawarah.

4) Badan Legislasi.

5) Badan Anggaran.

6) Badan Kerja Sama Antar-Parlemen.

7) Mahkamah Kehormatan Dewan.

8) Badan Urusan Rumah Tangga.

b) Kekuasaan Eksekutif

1) Konsil Kedokteran Indonesia.

2) Dewan Ketahanan Nasional.

3) Lembaga Ketahanan Nasional (Lemhannas).

4) Lembaga Ilmu Pengetahuan Indonesia (LIPI).

5) Badan Pengkajian dan Penerapan Teknologi (BPPT).

6) Badan Kepegawaian Negara (BKN).

7) Lembaga Administrasi Negara (LAN).

8) Dewan Pertimbangan Presiden.

9) Badan Pariwisata dan Ekonomi Kreatif.

10) Badan Pengawas Keuangan dan Pembangunan.

11) Badan Keamanan Laut.

c) Kekuasaan Yudikatif

${ }^{60}$ Indikator dalam menentukan state auxiliary organ bukan lembaga negara quasi ialah bahwa negara tersebut hanya menjalankan fungsi penunjang salah satu dari constitutional state organ dan tidak memiliki kewenangan yang bercirikan dua cabang kekuasaan atau lebih. 
Lembaga negara yang menunjang Mahkamah Agung ialah Komisi Yudisial. Komisi Yudisial menunjang Mahkamah Agung dalam hal pengawasan etik hakim agung.

\section{Kesimpulan}

Dalam menjalankan kekuasaan negara Indonesia, terdapat pemisahan kekuasaan. Implementasi pemisahan kekuasaan di Indonesia tidak mutlak menerapkan prinsip trias politica. Pemisahan kekuasaan di Indonesia dijalankan oleh lembaga negara yang memiliki tugas dan fungsi tertentu. Lembaga negara umumnya menjadi materi muatan dalam konstitusi. Sehingga, lembaga negara yang disebutkan dalam konstitusi merupakan constitutional state organ. Akan tetapi, ketidakluwesan amandemen konstitusi dan juga kebutuhan kenegaraan yang semakin kompleks melahirkan lembaga negara diluar konstitusi (state auxiliary organ). Lembaga-lembaga yang lahir diluar konstitusi ini pun berkembang dengan pesat dengan berbagai macam bentuk organisasi negara baik berupa lembaga, komisi, atau badan. Banyaknya state auxiliary organ di Indonesia berdampak terhadap ketidakjelasan kedudukan state auxiliary organ tersebut. Oleh karena itu, dalam penelitian ini penulis mencoba mengklasifikasikan kedudukan state auxiliary organ di Indonesia. Kedudukan state auxiliary organ di Indonesia dapat diklasifikasikan berdasarkan aturan pembentuknya, independensi kelembagaannya, dan fungsi dan tugas yang dimilikinya.

\section{Daftar Pustaka}

\section{Buku}

A. Fickar Hadjar, dkk. (2003). Pokok-Pokok Pikiran dan Rancangan Undang-Undang Mahkamah Konstitusi. Jakarta: KRHN dan Kemitraan.

Asshiddiqie, Jimly. (2005). Sengketa Kewenangan Antar Lembaga Negara. Cet. 1. Jakarta: Konstitusi Press.

(2006). Perkembangan dan Konsolidasi Lembaga Negara Pasca Reformasi.

Jakarta: Sekretariat Jenderal dan Kepaniteraan Mahkamah Konstitusi RI. . (2016). Perkembangan E Konsolidasi Lembaga Negara Pasca Reformasi.

Cet. III. Jakarta: Sinar Grafika.

Budiardjo, Miriam. (2002). Dasar-Dasar Ilmu Politik. Jakarta: Gramedia.

Daman, Rozikin. (1993). Hukum Tata Negara. Jakarta: PT. Raja Grafindo Persada.

Hamzah, Andi. (1986). Kamus Hukum. Jakarta: Ghalia Indonesia.

Huda, Ni'matul. (2005). Negara Hukum, Demokrasi, dan Judicial Review. Yogyakarta: UII Press.

HR, Ridwan. (2006). Hukum Administrasi Negara. Jakarta: PT. Raja Grafindo Persada. Jeddawi, Murtir. (2012). Hukum Administrasi Negara. Yogyakarta: Total Media. 
Juanda. (2006). Hukum Pemerintahan Daerah Pasang Surut Hubungan Kewenangan DPRD dan Kepala Daerah. Bandung: Alumni.

Kansil, CST. (2002). Pengantar Ilmu Hukum dan Tata Hukum Indonesia. Jakarta: Balai Pustaka.

Kansil, CST. (2004). Ilmu Negara Umum dan Indonesia. Jakarta: Pradnya Paramita.

Mustafa Luthfi dan M. Iwan Satriawan. (2014). Meneropong Komisi Informasi Publik". Malang: UB Press.

Ni'matul Huda, dkk. (2019). Mewujudukan Daulat Rakyat Melalui Pemilu yang Berkualitas. Yogyakarta: Pustaka Pelajar bekerja sama dengan LP3M UMY dan PK2P UMY.

Suny, Ismail. 1982. Pembagian Kekuasaan Negara. Jakarta: Aksara Baru.

Tauda, Gunawan A. (2012). Komisi Negara Independen. Yogyakarta: Genta Press.

Tim Penyusun Hukum Acara Mahkamah Konstitusi. (2010). Hukum Acara Mahkamah Konstitusi. Jakarta: Sekretariat Jenderal dan Kepaniteraan Mahkamah Konstitusi Republik Indonesia.

Tim Penyusun Komisi Yudisial. (2013). Puth Hitam Pengadilan Khusus. Jakarta: Pusat Analisis dan Layanan Informasi Sekretariat Jenderal Komisi Yudisial.

Tjandra, W. Riawan. (2014). Hukum Sarana Pemerintahan. Jakarta: Cahaya Atma Pustaka.

Utrecht. (1962). Pengantar Hukum Administrasi Negara Indonesia. Jakarta: Ichtiar.

Wahyono, Padmo. (2003). Ilmu Negara. Jakarta: Indo Hill. Co.

Widodo Ekatjahjana dan Totok Sudaryanto. (2001). Sumber Hukum Tata Negara Formal di Indonesia. Bandung: PT. Citra Aditya Bhakti.

Zoelva, Hamdan. (2001). Pemakzulan Presiden di Indonesia. Jakarta: Sinar Grafika.

\section{Artikel Jurnal}

Agustiwi, A. (2014). Keberadaan Lembaga Negara Pasca Amandemen UndangUndang Dasar 1945 di Indonesia. Jurnal Rechstaat Ilmu Hukum Fakultas Hukum UNSA Vol. 8, No.1.

Basarah, A. (2014). Kajian Teoritis Terhadap Auxiliary State's Organ Dalam Struktur Ketatanegaraan Indonesia. Jurnal MMH Vol.43, No.1.

Hantoro, N.M. (2016). Klasifikasi Jabatan dalam Kelembagaan Negara: Permasalahan Kategori Pejabat Negara. Jurnal Negara Hukum Vol.7, No.2.

Hendra Nurtjahjo. (2005). Lembaga, Badan, dan Komisi Negara Independen (State Auxiliary Agencies) di Indonesia: Tinjauan Hukum Tata Negara. Jurnal Hukum dan Pembangunan Vol.35, No.3. 
Mochtar, ZA. \& Satriawan, I. (2009). Efektivitas Sistem Penyeleksian Pejabat Komisi Negara di Indonesia. Jurnal Konstitusi No. 6, Vol.3.

Prasetyoningsih, N. (2014). Dampak Pemilihan Umum Serentak bagi Pembangunan Demokrasi Indonesia. Jurnal Media Hukum, Vol.21, No.2.

Ridlwan, Z. (2015). Cita Demokrasi Indonesia Dalam Politik Hukum Pengawasan DPR Terhadap Pemerintah. Jurnal Konstitusi Vol.12, No.2.

Siallagan, H. (2015). Problematics on Separation of Power Theory Implementation. Jurnal Dinamika Hukum, Vol.15, No.3.

Simamora, J. (2014). Tafsir Negara Hukum Dalam Prespektif Undang-Undang Dasar Negara Republik Indonesia Tahun 1945. Jurnal Dinamika Hukum Vol.14, No.3.

Sayuti. (2011). Konsep Rechtsstaat Dalam Negara Hukum Indonesia (Kajian Terhadap Pendapat Azhari. Nalar Fiqh Jurnal Kajian Ekonomi dan Kemasyarakatan Vol.4, No.2.

Sunarto. (2016). Prinsip Checks and Balances dalam Sistem Ketatanegaraan Indonesia. Jurnal Masalah-Masalah Hukum Vol.45, No.2.

Suparto. (2016). Pemisahan Kekuasaan, Konstitusi dan Kekuasaan Kehakiman yang Independen Menurut Islam. Jurnal Selat Vol.4, No.1.

Tauda, G.A. (2011). Kedudukan Komisi Negara Independen dalam Struktur Ketatanegaraan Republik Indonesia. Jurnal Pranata Hukum Vol.6, No.2.

Yulistyowati, E. Pujiastuti, E. \& Mulyani, T. (2016). Penerapan Konsep Trias Politica Dalam Sistem Pemerintahan Republik Indonesia: Studi Komparatif atas UndangUndang Dasar Tahun 1945 Sebelum dan Sesudah Amandemen. Jurnal Dinamika Budaya Vol18, No.2.

Zulfan. (2018). Analisis Pengaturan dan Praktik Pemisahan Kekuasaan Sistem Pemerintahan Presidensial Berdasarkan Konstitusi. Jurnal Media Hukum Vol.25, No.1.

\section{Laporan Penelitian}

Falaakh, Moh. Fajrul. (2009). “Redistribusi Kekuasaan Negara dan Model Hubungan Antarlembaga Negara dalam UUD 1945 Pasca Amandemen". Laporan Penelitian. Yogyakarta: WCRU-HTN Fakultas Hukum UGM.

Tim Pengkajian Hukum Tentang Hubungan Antar Lembaga Negara. (2005). Laporan Akhir Pengkajian Hukum Tentang Hubungan Lembaga Negara Pasca Amandemen UUD 1945. Jakarta: Badan Pembinaan Hukum Nasional.

\section{Prosiding}


Prasetyoningsih, N. Lailam, T. \& Anggia, P. (Editor), (2018). “Menagih Komitmen Pemerintah Mewujudkan Keadilan Sosial". Proceedings Seminar Nasional dan Call for Papers. Yogyakarta: LP3M UMY. 